\title{
The Function of a Shape as an Absolute Ground for Refusal
}

\author{
Natalie Schober
}

Published online: 23 January 2013

(C) Max Planck Institute for Intellectual Property and Competition Law, Munich 2013

\begin{abstract}
The focus of this work will be an analysis of the European conception of the functionality doctrine, which was originally invented and developed by United States' courts. The central debate revolves around the differing approaches taken by the European Court of Justice and Advocate General Mengozzi in the ECJ's recent Lego decision, concerning the classification of so-called hybrid shapes and the relevance of alternative shapes. In order to reconcile these differences with a coherent dogmatic understanding, these questions will be supplemented with the findings of US courts, specifically the ruling in the Traffix decision. The underlying idea of this comparative method is to find appropriate solutions to the questions that still appear to be unresolved at this stage in European trademark practice.
\end{abstract}

Keywords Trademark law · Functionality doctrine - Ground for refusal · Hybrid shapes · Alternative shapes · CTMR

\section{Introduction}

Traditionally, European legislations used to provide rather restrictive definitions of what constituted a trademark, confining the scope of protection to trade symbols, such as labels and brands. ${ }^{1}$ Under the current regime, the concept of a sign has expanded, extending its scope also to three-dimensional shapes. Particularly, the registration of functional shapes has proved to face difficulties in the past. Holding exclusive rights over functional shapes could deprive competing economic

${ }^{1}$ Cf. for example Sec. 68 TMA 1938.

N. Schober $(\bowtie)$

LL.M., London School of Economics

Choriner Straße 29, 10435 Berlin, Germany

e-mail: natalie.schober@gmx.de 
operators of the possibility of supplying a product incorporating that function, whatever shape it might take.

The protection of functional shapes is typically the province of patent law, which encourages innovation by granting inventors a monopoly over new product designs or functions for a limited period of time. ${ }^{2}$ Trademark law, on the other hand, is primarily concerned with the protection of identifying symbols, thereby preventing customer confusion. ${ }^{3}$ By granting trademark protection over product shape features, a monopoly could be obtained irrespective of whether such features qualify as patents and, even more significantly, could be extended forever. ${ }^{4}$ Allowing such a monopoly would therefore likely restrict freedom excessively in a sector where technical progress is based on a process of ongoing improvement of earlier innovations. 5

\section{Functionality Doctrine}

The significant differences between distinctive product features and other indicia of origin in the context of trademark protection were initially recognised by courts in the United States. ${ }^{6}$ In order to accommodate trademark law to the policies of patent law, US courts developed the policy that trademark rights could not validly be claimed for functional shapes or product features. ${ }^{7}$ Under this doctrine, imitation of "functional" product features is presumed to be "a legitimate competitive endeavour rather than a fraudulent attempt to divert the trade of another." 8 Once a design is held to be "functional", the design is available for all to copy as a matter of free competition.

The import of this doctrine into European trademark law has brought with it a need to clarify its application in European trademark practice. In order to demonstrate the dissenting approaches put forth by trademark applicants and their opponents, I will discuss their arguments concerning the de facto effects of functionality on trademark registration. The different approaches in applying the functionality doctrine in practice shall be weighed against the background of its American predecessor in order to find an appropriate solution.

\subsection{European Trademark Regulation}

The European Trademark Regulation (hereinafter CTMR) ${ }^{9}$ has adopted a rather similar understanding of the US functionality doctrine by excluding functional

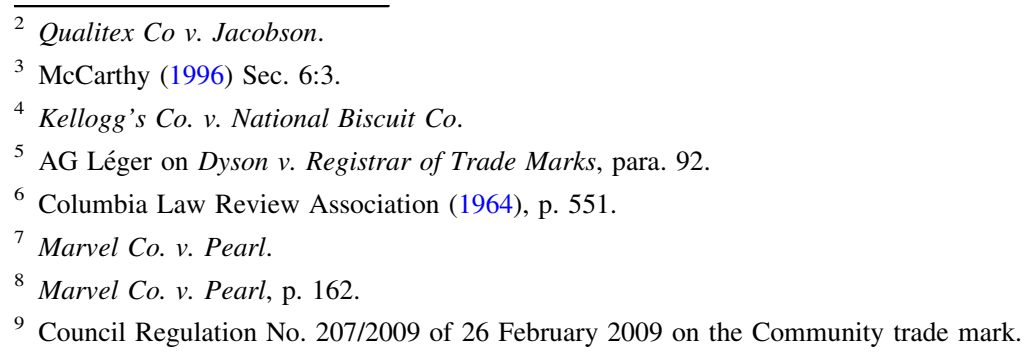


shapes from the sphere of registration. As will be discussed in detail, the absolute ground for refusal set out in Art. 7(1)(e)(ii) CTMR is of utmost importance in the context of functional shapes. Moreover, distinctiveness according to Art. 7(1)(b) CTMR will often play a role if a shape is held to be functional.

\subsubsection{Article 7(1)(e)(ii) CTMR}

Article 7(1)(e) CTMR provides for a "preliminary obstacle" to the registration of three-dimensional shapes. ${ }^{10}$ The functionality doctrine itself is reflected in Art. 7(1)(e)(ii) CTMR. According to this provision a sign may not be registered if it consists exclusively of the shape of goods, which is necessary to achieve a particular result. The principles for interpreting this wording were first set out in the Philips $v$. Remington judgement ${ }^{11}$ and later expanded in the Lego v. OHIM/Mega Brands decision. ${ }^{12}$ These cases have been the subject of detailed consideration by the ECJ and distinctly illustrate the difficulties that occur when registration is sought for functional shapes.

Both Philips and Lego put forth a variety of arguments in order to avoid the absolute effect of Art. 7(1)(e)(ii) CTMR that essentially rely on the proper interpretation of the terms "exclusively" and "necessary". They argued, that the scope of the provision did not exclude functional shapes per se from registration, but allowed the applicant to disprove the assumption of functionality if it could be shown that registration would not in fact place competitors in a disadvantageous position. Registration should thus only be refused in cases in which the registration of a shape would create a monopoly on technical solutions or on functional characteristics. ${ }^{13}$ Furthermore, it was argued that the addition of an essential arbitrary or decorative feature could render a shape non-functional in its entirety, thus allowing for trademark registration. ${ }^{14}$

To scrutinise these arguments one must determine how extensively the wording of the provision should be interpreted, taking into account the underlying public interest of the provision. ${ }^{15}$ As has been established in European case law, the twofold rationale of the provision seeks to prevent monopolies by ensuring that a shape whose essential characteristics perform a technical function may freely be used by all ${ }^{16}$ and to warrant the strict delineation of different industrial property rights. ${ }^{17}$

In Philips, the ECJ was asked specifically whether the registration should be excluded only in such cases in which it is shown that the essential features of the shape are attributable only to the technical result, hence when a shape is purely

\footnotetext{
10 Bently and Sherman (2009), p. 807.

11 Philips v. Remington, Case 299/99 (2002).

12 Lego v. OHIM/Mega Brands, Case C-48/09 P (2010).

13 Lego v. OHIM/Mega Brands, Case C-48/09 P (2010), para. 29.

14 Philips v. Remington, Case 299/99 (2002), para. 43.

15 Lego v. OHIM/Mega Brands, Case C-48/09 P (2010), para. 43; Windsurfing Chiemsee, paras. 25-27.

16 Philips v. Remington, Case 299/99 (2002), para. 76; Windsurfing Chiemsee, para. 25.

17 AG Mengozzi on Case 48/09 P 2010 para. 61.
} 
functional. Moreover, the ECJ was asked to determine whether the assumption under Art. 7(1)(e)(ii) CTMR could be overcome by establishing that there are alternative shapes available to competitors that can obtain the same technical result. These questions were reconsidered in Lego; however, it will be demonstrated that the answers have not yet been provided to an extent that may ensure legal certainty for European trademark applicants and the national courts.

2.1.1.1 "Exclusively" The ECJ recognised that the purpose of the provision was to prevent monopolies, in particular technical results by means of trademark protection. ${ }^{18}$ In this respect, the Court outlined that the term "exclusively" must be read in the light of the expression "essential characteristics which perform a technical function". ${ }^{19}$ A registration of such a trademark would have the result that "the exclusivity inherent in the trade mark right would limit the possibility of competitors supplying a product incorporating such a function or at least limit their freedom of choice in regard to the technical solution they wish to adopt in order to incorporate such function in their product". ${ }^{20}$

As regards the degree of functionality, the Court merely stated that Art. 7(1)(e)(ii) CTMR required that the essential functional features of that shape be attributable only to the technical result. ${ }^{21}$ This condition is certainly fulfilled when all essential characteristics of a shape are functional. The judgement however did not address shapes whose essential features are only partly functional. This vagueness raises the question of what effect arbitrary elements have on the registrability of a three-dimensional sign whose shape is otherwise dictated by its technical solution.

In the action that Lego brought against the contested decision of the Board of Appeal, the CFI (General Court) held that the addition of non-essential characteristics having no technical function could not prevent a shape from falling under the provision. ${ }^{22}$ Thus, the CFI concluded that the Grand Board of Appeal had correctly interpreted the term "exclusively" when analysing the functionality of the shape by reference to the essential characteristics only. ${ }^{23}$

In its Lego decision, the ECJ went on to elaborate on this question. Confirming that minor arbitrary elements were indeed irrelevant, it recognised that the situation would be different if a shape was comprised partly of essential functional elements, but also of essential non-functional elements. It assumed that the Council Regulation (EC) No. 40/94 would only be applicable where all essential characteristics of the sign were functional. ${ }^{24}$ Conversely, this would mean that where a shape incorporated a major, non-functional element, such as a decorative or

\footnotetext{
18 Philips v. Remington, Case 299/99 (2002), para. 67.

19 Philips v. Remington, Case 299/99 (2002), paras. 79, 80, 83.

20 Philips v. Remington, Case 299/99 (2002), para. 79.

21 Philips v. Remington, Case 299/99 (2002), para. 84.

22 Lego v. OHIM/Mega Brands, CFI, Case T-270/06, para. 38.

23 Lego v. OHIM/Mega Brands, CFI, Case T-270/06, para. 38.

24 Lego v. OHIM/Mega Brands, Case C-48/09 P (2010), para. 52.
} 
imaginative element, Art. 7(1)(e)(ii) CTMR should not apply and registration should be granted. ${ }^{25}$

To this stage, the ECJ thus purports a rather strict all-or-nothing approach. If a shape is purely functional, it shall be excluded from trademark protection. If on the other hand it is to some degree non-functional because it is comprised at least in part of major arbitrary elements, registration shall be granted. It follows that this approach does not adequately tackle the problem that different degrees of functionality may require different modes of trademark protection. Despite its advantage of allowing for a clear-cut categorisation when put into practice, this approach seems to lack a differentiated legal analysis. Thus, with regards to hybrid shapes with partly functional and non-functional essential features, the functionality test under European case law needs to be further refined to determine whether the registration of a trademark will bear the risk of conflicting with the underlying public interest.

2.1.1.2 "Necessary" The second requirement that needs clarification concerns the "necessity" of the shape for the given technical result and thus constitutes the standard of causality. The principles for interpreting the term "necessary" were also established in the Philips judgement. ${ }^{26}$ Attempting to vitiate this requirement, Philips had argued that the shape of its razor did not fall under the exclusion rule of Art. 7(1)(e)(ii) CTMR because the function of the razor could also be achieved by means of alternative shapes. ${ }^{27}$ To prove its point, Philips repeatedly referred to the purpose of the provision, namely to prevent obtaining a monopoly in a particular technical result by means of trademark protection. Accordingly, if that technical result could be obtained by other shapes readily available to competitors, the registration of a mark consisting of a shape which has a technical result would impose no unreasonable restraint on industry and innovation. More generally, Philips argued that "provided the trademark owner could show that some other shape will also do the job, their sign will not fall within the exclusion no matter how functional it may be". 28

The ECJ countered this argument by stating that there was nothing in the wording to allow such a conclusion. The Court hence applied a broad conception of functionality, suggesting that there be a mere causality between a shape and its function. It ruled that the existence of functionally equivalent shapes, which could achieve the same technical result, were not in themselves sufficient to overcome this ground of refusal. ${ }^{29}$

In the Lego case, the applicant argued anew that the scope of Art. 7(1)(e)(ii) CTMR did not exclude functional shapes per se from registration, but allowed the applicant to disprove the assumption under the provision. Only if the shape was the only one that could perform the particular function, did the registration of a sign

\footnotetext{
${ }^{25}$ Lego v. OHIM/Mega Brands, Case C-48/09 P (2010), para. 52.

26 Philips v. Remington, Case 299/99 (2002), paras. 82, 83, 84.

27 Philips v. Remington, Case 299/99 (2002), para. 67.

28 Bently and Sherman (2009), p. 811.

29 Philips v. Remington, Case 299/99 (2002), paras. 81, 83, 84.
} 
impose an unreasonable restraint on innovation. ${ }^{30}$ The existence of alternative shapes using the same technical solution should therefore be the correct criterion for establishing whether a trademark may give rise to a monopoly. ${ }^{31}$ However, the ECJ repeatedly countered such an amenable understanding of the term "necessary". 32

Again, the Court appears to have approached the question of necessity quite abstractly, leaving the issues raised by the applicants somewhat unresolved. What would be desirable is a more detailed analysis under the scope of Art. 7(1)(e)(ii) CTMR, taking into account the purpose of the provision in a more differentiated manner.

\subsubsection{Article 7(1)(b) CTMR: Distinctiveness}

Since the relevant consumer may not think of a functional shape as communicating a distinguishing function, but rather as serving a technical purpose, particularly the requirement of "distinctiveness" could be another significant obstacle to the registration of a shape. In Linde Winward and Rado, the ECJ clarified that neither the wording nor the purpose of Art. 7(1)(b) CTMR allowed for a stricter standard when determining the distinctiveness of a three-dimensional shape. ${ }^{33}$ Nevertheless, it recognised that it might be more difficult in practice to prove distinctiveness of a trademark that consists of a three-dimensional shape than for another category of trademark. ${ }^{34}$ In an attempt to stretch that practical concern further, Remington argued that only the addition of a capricious element would allow a functional shape to acquire a sufficient level of distinctiveness. ${ }^{35}$ The ECJ struck down this argument, stating that the "distinctiveness" of a threedimensional shape did not require the addition of a mere embellishment without any functional purpose. ${ }^{36}$

\subsubsection{Determining Functionality (Modus Operandi)}

Having considered some of the theoretical concerns relating to functional shapes, it is necessary to define how these issues shall be approached in practice. When determining whether a shape is functional the criteria that appear relevant are the technical data, especially the information contained in prior patents, the existence of alternative shapes and the consumer perception.

So far, the actual practice has established a rather high threshold for the registration of functional shapes. Most courts and authorities, in observance of the ECJ's jurisprudence, appear to apply Art. 7(1)(e)(ii) CTMR in a rather cautious

\footnotetext{
30 Philips v. Remington, Case 299/99 (2002), para. 67.

31 AG Mengozzi on Lego v. OHIM, para. 23.

32 Lego v. OHIM/Mega Brands, Case C-48/09 P (2010), paras. 53 et seq.

33 Linde Winward, para. 46.

34 Linde Winward, para. 48.

35 Philips v. Remington, Case $299 / 99$ (2002), para. 43.

36 Philips v. Remington, Case 299/99 (2002), paras. 49, 50.
} 
manner. ${ }^{37}$ The diverging approaches taken by the ECJ and the Advocate General on the occasion of the Lego decision will be discussed and compared in order to provide for a consistent dogmatic guidance to facilitate the harmonisation of the judicial practice of national courts and registration bodies.

2.1.3.1 The ECJ's Approach According to the ECJ, the assessment of functionality requires the application of two relevant steps.

\subsection{Identification of the Essential Characteristics Firstly, the competent} authority should identify the essential characteristics on a case-by-case basis. ${ }^{38}$ In determining the essential characteristics of a sign, the body for registration may either base its assessment simply on the overall impression of the shape or, if necessary, examine each of the individual components. ${ }^{39}$ Hence, the identification of the essential characteristics may, depending on the complexity of the shape, be carried out by means of a simple visual inspection or be based on a detailed technical analysis. In the latter case, the authority should rely on relevant criteria, such as surveys or expert opinions. ${ }^{40}$ Since the assessment of technical functions extends to the scope of patent protection, trademark examiners should also particularly rely on the technical data contained in prior patents. ${ }^{41}$

Lego argued that "essential characteristics" were synonymous with "dominant and distinctive" elements and must therefore be assessed from the perspective of a reasonably informed and circumspect consumer only. ${ }^{42}$ In its appeal before the CFI, Lego had submitted that the Grand Board of Appeal misunderstood the impact of previous patent protection on the assessment of whether a shape is functional, and that it failed to observe that one and the same item can be protected by various industrial property rights. ${ }^{43}$

According to the ECJ this reasoning could not be upheld since the consumer's opinion was relevant only at the stage of distinctiveness, however not when assessing functionality. ${ }^{44}$ The ECJ clarified that unlike in Art. 7(1)(b) CTMR, where the perception of the target public must be taken into account, such an obligation could not be imposed in the context of Art. 7(1)(e)(ii) CTMR. ${ }^{45}$ Hence, the perception of the target consumer should never be a decisive element when establishing functionality and could, at most, be one of the relevant criteria of assessment on which the competent authority can rely.

\footnotetext{
37 "Study on the Overall Functioning of the European Trade Mark System", presented by the Max Planck Institute for Intellectual Property and Competition Law, Munich, 2.27.

38 Lego v. OHIM/Mega Brands, Case C-48/09 P (2010), para. 70.

39 Lego v. OHIM/Mega Brands, Case C-48/09 P (2010), para. 70.

40 Lego v. OHIM/Mega Brands, Case C-48/09 P (2010), para. 71.

41 Lego v. OHIM/Mega Brands, Case C-48/09 P (2010), para. 71.

${ }^{42}$ Lego v. OHIM/Mega Brands, Case C-48/09 P (2010), para. 63; with reference to Gut Springenheide and Tursky, para. 31.

43 Lego v. OHIM/Mega Brands, CFI, Case T-270/06, paras. 63, 43.

44 Lego v. OHIM/Mega Brands, Case C-48/09 P (2010), para. 75.

45 Lego v. OHIM/Mega Brands, Case C-48/09 P (2010), para. 75.
} 
2.1.3.1.2 "Necessity" of the Essential Characteristics Once the essential characteristics of the sign have been identified, one must assess whether those characteristics perform the technical function of the product concerned. ${ }^{46}$ When engaging in the functionality analysis the ECJ suggests an autonomous approach focusing on the shape itself and the technical data relating to it, including the documents relating to prior patents. ${ }^{47}$ Clearly, the existence of alternative shapes should be irrelevant when making this assessment: the body of registration should analyse the sign filed with a view to its registration as a trademark, and not signs consisting of other shapes of goods. ${ }^{48}$

Moreover, the body of registration has to assess whether the identified essential characteristics all perform a technical function. ${ }^{49}$ The ECJ thus champions the view that shapes partially comprised of non-functional elements, such as decorative or imaginative elements, are excluded from the functionality analysis under Art. 7(1)(1)(ii) CTMR. ${ }^{50}$

2.1.3.2 The Advocate General's Approach According to the Advocate General, the application of Art. 7(1)(e)(ii) CTMR requires certain methodological guidelines that enable a more nuanced approach on the basis of the Philips judgement. ${ }^{51} \mathrm{He}$ introduces a three-step approach that could assist the courts in deciding on the question of functionality.

\subsection{First Stage: Identification of Essential Characteristics and Necessary} Connection As the Advocate General proposes, the registration body should primarily identify the most important elements of the shape and determine if they are functional. Thereby, one should examine if there is a necessary connection between the essential characteristics and the technical result. ${ }^{52}$ This first stage hence complies with the two-prong functionality test as suggested by the ECJ.

The Advocate General agrees that the procedure to be applied at this initial stage should rest upon an entirely autonomous approach, focusing only on the shape itself and its technical specifications. He agrees with the ECJ that patents constitute a powerful presumption that essential characteristics of the shape perform a technical function. ${ }^{53}$ In contrast, he contends, still in line with the approach taken by the ECJ, that the existence of alternative shapes is irrelevant at this stage. If all features are held to be functional at this stage, the test is over and registration shall not be granted. If it turns out, however, that some features are not functional, then the

\footnotetext{
${ }^{46}$ Lego v. OHIM/Mega Brands, Case C-48/09 P (2010), para. 84.

47 Lego v. OHIM/Mega Brands, Case C-48/09 P (2010), para. 85.

48 Lego v. OHIM/Mega Brands, Case C-48/09 P (2010), para. 84.

49 Lego v. OHIM/Mega Brands, Case C-48/09 P (2010), para. 72.

50 Lego v. OHIM/Mega Brands, Case C-48/09 P (2010), para. 72.

51 AG Mengozzi on Lego v. OHIM, paras. 61 et seq.

52 AG Mengozzi on Lego v. OHIM, para. 65.

53 AG Mengozzi on Lego v. OHIM, para. 67.
} 
Advocate General proposes, contrary to the ECJ's opinion, that the registration body shall proceed to the second stage. ${ }^{54}$

2.1.3.2.2 Second Stage: Existence of Alternative Shapes At the second stage, the body responsible for registration is confronted with a hybrid shape whose essential features are only partly functional. In contrast to the understanding of the ECJ, the Advocate General champions the view that the provision is in fact applicable in this scenario due to the underlying public interest. Since he considers the examination of a hybrid shape to be more complex than that of a purely functional shape, he proposes two solutions. Firstly, he suggests the possibility of allowing for disclaimers in order to protect only the non-functional part. ${ }^{55}$ This would, however, result in a heavy and impracticable analysis of separating functional features from their non-functional counterparts and subjecting them to different tests of functionality. ${ }^{56}$

The second solution, which seems to be practically more relevant, relies on an assessment of whether competition will be impeded by the use of the trademark in question. This assessment is nothing but a means to ensure that the underlying interest of allowing free competition is fulfilled. When examining a purely functional shape, this assessment can be carried out by way of an autonomous analysis under the first stage. In contrast, the complexity of a hybrid shape analysis additionally requires a concrete market analysis. Thus, under the second stage, the comparison with alternative market options finally becomes relevant. Since the purpose of the provision is to protect competition, the examination of a sign composed in part of functional elements would have to be subject to a requirement that any industrial property right granted must not lead to significant non-reputationrelated disadvantage for competitors. ${ }^{57}$

2.1.3.2.3 Third Stage: Distinctiveness Finally, once those obstacles have been overcome by showing that the shape does not harm competition, the bodies responsible for determining the functionality of a shape of this hybrid type must ascertain whether the trademark has distinctive character. At this point, the overall impression conveyed by the sign, the point of view of the consumer, and the goods or services for which registration has been sought, are relevant. ${ }^{58}$

\subsubsection{Unresolved Problems}

When contrasting the approaches of the Advocate General and the ECJ, it becomes apparent that there are still divergences that have to be resolved in order to reach a consistent understanding under European trademark practice. The Advocate

\footnotetext{
54 AG Mengozzi on Lego v. OHIM, para. 68.

55 AG Mengozzi on Lego v. OHIM, para. 73.

56 "Study on the Overall Functioning of the European Trade Mark System", presented by the Max Planck Institute for Intellectual Property and Competition Law, Munich, para. 2.46.

57 AG Mengozzi on Lego v. OHIM, para. 74.

58 AG Mengozzi on Lego v. OHIM, para. 75.
} 
General's suggestion that the existence of alternative shapes should be taken into account within the second stage of the functionality analysis seems to be inextricably intertwined with the question of whether Art. 7(1)(e)(ii) CTMR is in fact applicable to hybrid shapes. The relevance of alternative shapes raises the follow-up question, under which circumstances a true alternative would be given. These questions shall be considered in detail.

\subsubsection{Application of Art. 7(1)(e)(ii) CTMR for Hybrid Shapes In the precedent} cases Philips and Lego, the ECJ had not yet been confronted with a situation in which it had to deal with varying degrees of functionality since it considered the signs in question to be purely functional. By ruling that the addition of essential non-functional characteristics would prevent a shape from falling under the provision, it failed to address this question appropriately.

The situation in which a court is confronted with a hybrid shape, however, is much more complex. Indeed, so far, this question has not yet come up in the rulings of the national courts. The ECJ's omission to make a differentiated ruling on this matter, will presumably also tempt national courts in the future to avoid this problem by classifying any arbitrary features of the shape as non-essential, meaning that their existence will be irrelevant for the assessment of functionality.

Despite its all-or-nothing approach, it seems that the ECJ has not overlooked the situation of hybrid shapes entirely. According to the Court hybrid shapes allow for alternatives with equivalent functionality so that there exists no risk that competitors will be deprived of access to the technical solution. ${ }^{59}$ This contradicts the Advocate General's reasoning to include such shapes in the functionality analysis and submit them to a careful examination at a later stage. Interestingly though, the ECJ's reasoning seems to comply with the argument desperately raised by the trademark applicants: that the existence of alternative shapes could disprove the functionality of a shape. Thus, the approaches taken by the ECJ and the Advocate General show that the applicability of the provision for hybrid shapes is inextricably intertwined with the question of whether the availability of alternative shapes can disprove the assumption made under Art. 7(1)(e)(ii) CTMR.

The ECJ's view that only purely functional shapes are barred from trademark protection invites the question whether it was already the intention in the Philips judgement to exclude hybrid shapes from the scope of Art. 7(1)(e)(ii) CTMR. A strict interpretation of Philips would indeed preclude Art. 7(1)(e)(ii) CTMR from being applied to hybrid shapes, ${ }^{60}$ since paragraph 84 of that judgement states that a sign consisting exclusively of the shape of a product is unregistrable "[...] if it is established that the essential functional features of that shape are attributable only to the technical result." 61 However, it is reasonable to assume that by making this statement, Philips focused too narrowly on the facts of the case at hand. ${ }^{62}$

\footnotetext{
59 Lego v. OHIM/Mega Brands, Case C-48/09 P (2010), para. 75.

60 AG Mengozzi on Lego v. OHIM, para. 69.

61 Philips v. Remington, Case $299 / 99$ (2002), para. 84.

62 AG Mengozzi on Lego v. OHIM, para. 69.
} 
Firstly, it would be unreasonable to assume that shapes would solely be comprised of technical elements. In the modern market, economic operators compete by providing both technically efficient, and at the same time eye-catching products. ${ }^{63}$ Given the high degree of competition, a purely functional product, completely devoid of any design element, would be extremely difficult to merchandise. A proper classification embracing the aesthetic aspect of a shape would place the practical relevance of the provision in doubt. It is therefore questionable if Philips and Lego are really concerned with products in which aesthetic considerations play no role. According to Advocate General Ruiz-Jarabo Colomer, the three rotary-headed shaver seems to be the perfect example for a purely functional shape. ${ }^{64}$ On the other hand, Philips, although contending that its sign was minimalist, stated in its defence that the registered sign reflected only one of the various ways of achieving the same technical result. ${ }^{65}$ This implies that the sign contains an element of arbitrariness and is therefore not only a "combination of technical features produced to achieve a good practical design", as was found by the national court. ${ }^{66}$

Secondly, looking at the public interest underlying Art. 7(1)(e)(ii) CTMR, which is to ensure that a functional shape may freely be used by all by not allowing individuals to perpetuate exclusive rights relating to technical solutions, it seems reasonable to give broad effect to that provision and to also include this hybrid type of shape involving functional and non-functional characteristics. ${ }^{67}$ As a result, the examination becomes merely more complex. ${ }^{68}$

Thirdly, a strict interpretation of Philips would lead to arbitrary results. The registrability of a shape would depend solely on the court's own classification of a shape as purely functional or hybrid. As a consequence, the appellant would be subjected to the mercy of the court and its formal analysis. Therefore, it seems reasonable to apply Art. 7(1)(e)(ii) CTMR also for hybrid shapes and exclude certain shapes on the grounds of a flexible, more elaborate case-by-case analysis as suggested by the Advocate General.

2.1.4.2 Existence of Alternative Shapes Furthermore, the question whether a functional shape is caught by the exclusion rule in Art. 7(1)(e)(ii) CTMR, even where the same technical result can be achieved by alternative shapes, requires some more clarification.

2.1.4.2.1 Practical Considerations In the Lego decision, the ECJ repeatedly rejected the argument that the existence of alternative shapes could preclude the application of the absolute ground for refusal. ${ }^{69}$ However, the abstract freedom in

\footnotetext{
63 Bang \& Olufsen v. OHIM, para. 26.

64 AG Ruiz-Jarabo Colomer on Philips v. Remington, para. 20.

65 AG Ruiz-Jarabo Colomer on Philips v. Remington, para. 21.

66 AG Ruiz-Jarabo Colomer on Philips v. Remington, para. 26.

67 AG Mengozzi on Lego v. OHIM, para. 70.

68 AG Mengozzi on Lego v. OHIM, para. 71.

69 Lego v. OHIM/Mega Brands, Case C-48/09 P (2010), paras. 53 et seq.
} 
design does not automatically mean that the registration of the shape would have no effect on the availability of these alternatives to other competitors. ${ }^{70}$ The registration of a purely functional shape not only prevents competitors from using the shape itself, but also from using a similar shape. Thus, a significant number of alternative shapes might therefore in fact not be available at all, especially those which are still attractive to the consumer from a functional perspective. ${ }^{71}$ This effect would be even more evident in cases in which various purely functional shapes were registered simultaneously, preventing competitors from manufacturing and marketing an entire range of goods. ${ }^{72}$

2.1.4.2.2 National Approaches The relevance of this problem is emphasised by the fact that there seem to be diverging approaches in national jurisprudence. The underlying policy, common to both national and Community trademark law, has not been sufficient to harmonise judicial practice completely. ${ }^{73}$

The German Federal Supreme Court has recently confirmed the principles of the ECJ in its German 2010 Lego decision and applied the absolute ground for refusal set out in Art. 7(1)((e)(ii) CTMR despite the existence of equivalent alternative shapes. ${ }^{74}$ However the approach taken in this recent decision stands in contradiction to its former approach. ${ }^{75}$ The German Federal Supreme Court used to base its assessment of functionality on the question whether there were alternative possibilities which would allow the manufacturer to develop products that are comprised of other shapes. ${ }^{76}$ Applying this approach to the functionality analysis of a bonnet of a car, the Court recognised that for a car manufacturer, the scope of creative design is confined due to technical requirements, such as the choice of a suitable material, the functionality of visible parts, aerodynamics and elements of safety. ${ }^{77}$ However, it concluded that, despite these technical specifications, Art. 7(1)(e)(ii) CTMR would not apply since the bonnet of a car could be subject to alterations and significant deviations from the standard shape, allowing the producer to create an individualised and self-contained design. ${ }^{78}$

\footnotetext{
70 Lego v. OHIM/Mega Brands, Case C-48/09 P (2010), para. 55.

71 Lego v. OHIM/Mega Brands, Case C-48/09 P (2010), paras. 56, 60.

72 Lego v. OHIM/Mega Brands, Case C-48/09 P (2010), para. 57.

73 AG Mengozzi on Lego v. OHIM, para. 57.

74 German Federal Supreme Court, 16 July 2009, Case No. I ZB 53/07, 2010 GRUR 231 - Legostein.

75 Ingerl and Rohnke (2010), p. 55.

76 German Federal Supreme Court, 15 December 2006, Case No. I ZB 33/04, 2006 GRUR 679, para. 14 Porsche Boxter; German Federal Supreme Court, 24 May 2007, Case No. I ZB 37/04, 2008 GRUR 71 Fronthaube.

77 German Federal Supreme Court, 15 December 2006, Case No. I ZB 33/04, 2006 GRUR 679, para. 14 Porsche Boxter; German Federal Supreme Court, 24 May 2007, Case No. I ZB 37/04, 2008 GRUR 71, para. 16 - Fronthaube.

78 German Federal Supreme Court, 15 December 2006, Case No. I ZB 33/04, 2006 GRUR 679, para. 14 Porsche Boxter; German Federal Supreme Court, 24 May 2007, Case No. I ZB 37/04, 2008 GRUR 71, para. 16 - Fronthaube.
} 
The Swedish courts have held that a shape must be regarded as purely functional where no other shape allows the same function to be performed. ${ }^{79}$ In contrast, both the French and the United Kingdom governments take the view that the ground for refusal under Art. 7(1)(e)(ii) CTMR cannot be overcome by establishing that there are other shapes capable of achieving the same technical result. ${ }^{80}$

2.1.4.2.3 Literal and Teleological Interpretation of Art.7(1)(e)(ii) CTMR On the occasion of the Philips decision, AG Ruiz-Jarabo Colomer approved of the reluctance of the UK court to acknowledge the relevance of alternative designs: "there is nothing in the wording of Art. 7(1)(e)(ii) CTMR which makes it possible to conclude that a merely functional shape could be registered if another shape, capable of achieving a comparable result, exists." 81 It suffices that the signs of which the trademark consists should be comprised exclusively of features that are necessary in order to achieve a particular technical result. ${ }^{82}$ This literal interpretation can just as easily be applied to the other main language versions of the Directive. $^{83}$

AG Ruiz-Jarabo Colomer supported this literal interpretation by reference to what he saw as the immediate purpose in barring registration of merely functional shapes or shapes that give substantial value to the goods, namely to prevent trademark law from extending the life of other intellectual property rights, which the legislature has sought to make subject to a limited period of time. ${ }^{84}$ Indeed, the Advocate General found further systematic support in the slightly different scope of exclusion of functional designs in the EU Design Regulation, which, he maintained, would deny protection only for design features that are "solely dictated by technical function." 85 The Trademark Regulation, which in a broader sense excludes from its protection "signs that are necessary to obtain a technical result", is thus more easily triggered than the Design Directive exclusion. ${ }^{86}$ This means that a functional design may still be eligible for protection if it can be shown that the same technical function could be achieved by another form. ${ }^{87}$

It follows that the bar for excluding a functional shape from legal protection is higher for designs than for trademarks. This is logical considering that the function and scope of design and trademark protection are completely different from one another. ${ }^{88}$ Trademarks indicate origin, thereby protecting the identity of the goods. Designs-like patents_-seek to protect the goods, in their own right, as an economic

\footnotetext{
79 AG Mengozzi on Lego v. OHIM, para. 57.

80 Philips v. Remington, Case $299 / 99$ (2002), para. 71.

81 AG Ruiz-Jarabo Colomer on Philips v. Remington, para. 28.

82 AG Ruiz-Jarabo Colomer on Philips v. Remington, para. 28.

83 AG Ruiz-Jarabo Colomer on Philips v. Remington, para. 29.

84 AG Ruiz-Jarabo Colomer on Philips v. Remington, para. 30-31.

85 Article 8(1) Community Design Regulation No. 6/2002.

86 http://works.bepress.com/graeme_dinwoodie/36; AG Ruiz-Jarabo Colomer on Philips v. Remington, paras. 32-34.

87 AG Ruiz-Jarabo Colomer on Philips v. Remington, para. 34.

88 AG Ruiz-Jarabo Colomer on Philips v. Remington, para. 36.
} 
factor: i.e. their substantial value (in the case of designs) or the value, which derives from their technical performance (in the case of patents). ${ }^{89}$ Moreover, whereas trademarks are unlimited in time, designs are limited like patents. Hence, it is appropriate to use a stricter test for excluding functional or ornamental shapes from registration as trademarks than that to separate designs from patents. ${ }^{90}$ Given the similar nature and scope of designs and patents, it makes sense that the European legislator is less concerned with the strict delineation between patents and designs than by that which ought to exist between patents and trademarks. Moreover, this makes it easier to protect designs that combine functional and aesthetic features. ${ }^{91}$

\subsection{Technical Solution Versus Technical Analysis Lego argued that} although Art. 7(1)(e)(ii) CTMR precludes from registration shapes for which protection would constrain competition, it does not seek to preclude from registration any shape performing a technical function. ${ }^{92}$ Thus, it could be helpful to inquire into an analysis between the technical solution and the technical result when determining whether a shape is functional. ${ }^{93}$ Under this analysis one should distinguish whether the alternative shapes incorporate the same technical solution or whether the alternatives can only be based on alternative solutions. The latter case indicates that the shape is dictated by the technical result and thus places a higher burden on effective competition. This approach constitutes another attempt to modify the ECJ's all-or-nothing approach, according to which hybrid shapes should be excluded per se from the application of Art. 7(1)(e)(ii) CTMR.

The ECJ has dismissed the relevance of the existence of alternative shapes without making this distinction. ${ }^{94}$ One should nevertheless examine whether the distinction has any effect. If competitors are forced to employ different solutions in order to alternate the shape, we can assume that the solution does not allow for variation, meaning that the shape is strictly dictated by its function. Where the shape is dictated by the technical result, the scope for functionally equivalent alternative shapes will be limited, if not reduced, to zero. Hence, a concrete market analysis, taking into account the availability of alternative shapes would go astray. However, an alternative shape using the same solution indicates that the solution allows for variation. This would be the case of a hybrid shape.

Even if one takes into account the availability of functionally equivalent market alternatives by distinguishing between the technical solution and the technical result of a shape, one does not obtain a more sophisticated constitutive assessment method of functionality. The distinction merely reaffirms that the existence of alternative shapes is relevant only when the body of registration has already identified major non-functional parts when making the assessment. The

\footnotetext{
89 AG Ruiz-Jarabo Colomer on Philips v. Remington, para. 37.

90 AG Ruiz-Jarabo Colomer on Philips v. Remington, para. 38.

91 AG Ruiz-Jarabo Colomer on Philips v. Remington, para. 37.

92 Lego v. OHIM/Mega Brands, Case C-48/09 P (2010), para. 30.

93 Lego v. OHIM/Mega Brands, Case C-48/09 P (2010), para. 30.

94 Philips v. Remington, Case 299/99 (2002), paras. 81 and 83; now also affirmed by the German Federal Supreme Court, 16 July 2009, Case No. I ZB 53/07, 2010 GRUR 231 - Legostein.
} 
application of this analysis is therefore circular and should not be attributed too much importance by the courts.

2.1.4.2.5 Interconnection Between Alternative and Hybrid Shapes The general reluctance that most of the European courts show towards the effect of alternative shapes on the functionality analysis, raises the question if the availability of alternative shapes has no impact at all on the registrability of functional shapes as trademarks. As shown, the ECJ does in fact believe that the availability of alternative shapes plays a role. ${ }^{95}$ Even if the ECJ rejects to include the existence of alternative shapes into the functionality analysis, it is determined to exclude all shapes which contain essential non-functional elements from the scope of Art. 7 CTMR due to the fact that such hybrid shapes bear no risk that the availability of the technical solutions will be impaired. ${ }^{96}$ Hence, we can see that the effect of alternative shapes on the question of functionality is strongly intertwined with the question whether only purely functional shapes fall under the exclusion rule.

\subsection{United States: Functionality Doctrine}

In light of these dissenting conceptions of functionality, it could be interesting to look into the refinements of the American doctrine which can be traced back almost to the beginning of the twentieth century ${ }^{97}$ and which has shaped the European notion of functionality. The aim of this direct comparison is to discover suitable methodical solutions in order to reconcile the all-or-nothing approach taken by the ECJ with the more differentiated view proposed by AG Mengozzi.

In the US legal system, traditional trademark infringement law is a part of the broader law of unfair competition and was predominantly codified in the Trademark Act of 1946 (Lanham Act). ${ }^{98}$ While the courts applied the functionality doctrine for decades as a matter of public policy, the doctrine only appeared as a non-statutory rule. $^{99}$ As late as in 1998, the US Congress finally amended the Lanham Act by codifying the functionality rule as an explicit ground for opposition and cancellation of registration and a statutory defence to an incontestably registered mark. ${ }^{100}$

Under the American conception, the functionality doctrine essentially excludes from registration all shapes if their appearance is based on their technical function and not on their distinctiveness. ${ }^{101}$ When trying to circumscribe the exact scope of the functionality doctrine, it seems that there are as many definitions in American case law of what is "functional" as there are courts. ${ }^{102}$ Since the functionality cases

\footnotetext{
95 See supra 2.1.4.1.

96 Lego v. OHIM/Mega Brands, Case C-48/09 P (2010), para. 72.

97 Marvel Co. v. Pearl (1917).

98 Moseley v. V Secret Catalogue, Inc.

99 McCarthy (1996), Sec. 7:63.

100 McCarthy (1996), Sec. 7:63.

101 Thomas \& Betts Corp. v. Panduit Corp., 1026, 1031.

102 McCarthy (1996), Sec. 7:69.
} 
do not easily weave together to produce a coherent jurisprudence, ${ }^{103}$ the focus should be on those cases that can be perceived as cornerstones in the doctrine, carving the way for today's perception of registrable shapes also in Europe.

What is evident from the outset is that there seem to be two major positions on how to define functionality. While the narrow approach focuses strictly on utilitarian features, the other approach extends its scope to any form of utility, purporting the wider concept of aesthetic functionality. These two positions will be contrasted and aligned to the established concept of the so-called competitive need test.

\subsubsection{The Traditional Rule: Inwood (Supreme Court)}

Traditional definitions of functionality embraced only technical product features. ${ }^{104}$ Under this notion, functionality was understood in a strictly utilitarian sense. Only if a feature gave the product more utility, or contributed to the economy of manufacture, the features were considered to be "functional" and thus incapable of trademark protection. ${ }^{105}$ In the groundbreaking 1982 Inwood decision, Justice O'Connor purported a utilitarian, engineering-driven conception, defining functionality in a way which was later recognised by the US Supreme Court as the "traditional rule": "In general terms a product feature is functional, and cannot serve as a trademark, if it is essential to the use or purpose of the Article or if it affects the cost or quality of the Article." ${ }^{106}$ The Inwood definition is often referred to as "utilitarian" functionality, as it relates to the performance of the product in its intended purpose. ${ }^{107}$ The benefit of this approach is that it reflects a literal understanding based on an etymological reasoning.

\subsubsection{Aesthetic Functionality (Ninth Circuit)}

Despite this strictly utilitarian conception of functionality, US trademark practice embraces the idea that features can also be functional in a much broader sense. The doctrine of aesthetic functionality may preclude aesthetic product features from trademark registration where doing so would stifle legitimate competition. ${ }^{108}$ This may be the case where a trademark serves a "significant non-trademark function" which exceeds the typical trademark purpose of source identification. ${ }^{109}$ The doctrine of aesthetic functionality is often traced to a comment in the 1938 Restatement of Torts: "When goods are bought largely for their aesthetic value,

\footnotetext{
103 Au-Tomotive Gold, Inc. v. Volkswagen of America, Inc.

104 Litman (1982), p. 7; Smith, Kline \& French Laboratories v. Clark \& Clark.

105 McCarthy (1996), Sec. 7:64.

106 Inwood Laboratories, Inc. v. Ives Laboratories, Inc.

107 Au-Tomotive Gold, Inc. v. Volkswagen of America, Inc.

108 Au-Tomotive Gold, Inc. v. Volkswagen of America, Inc.

109 Au-Tomotive Gold, Inc. v. Volkswagen of America, Inc.
} 
their features may be functional because they definitely contribute to that value and thus aid the performance of an object for which the goods are intended."110

The doctrine blossomed in Pagliero v. Wallace China Co., when Wallace China, a manufacturer of vitrified china, brought an action to prohibit a competitor from using a series of decorative patterns and a corresponding list of names. Since the product in question was bought largely for its aesthetic value, the court fashioned a wide definition of functionality that included aesthetic appeal. It held that "a functional characteristic is an important ingredient in the commercial success of the product. In that case, the interest in free competition permits its imitation in the absence of a patent or copyright." 111 Applying that test, the china patterns were deemed "functional" because the "attractiveness and eye-appeal" of the design is the primary benefit that consumers seek in purchasing china. ${ }^{112}$

This view has been widely criticised as being too broad, eventually swallowing up much, perhaps all, of trademark law. ${ }^{113}$ Taken to its limits, this doctrine would permit a competitor to trade on any mark simply because there is some "aesthetic" value to the mark that consumers desire, distorting both basic principles of trademark law and the doctrine of functionality in particular. ${ }^{114}$ Although a leading commentator predicted "the final end of the Ninth Circuit's 50 year flirtation with the aesthetic functionality theory," 115 the doctrine, albeit restricted over the years, retains some limited vitality. ${ }^{116}$

\subsubsection{Competitive Need Test}

The rationale for the functionality doctrine is based on the policy that courts must preserve free and effective competition by ensuring that competitors can copy features they need in order to "compete effectively." 117 Therefore, the number of alternative designs available is often used as a guide to compliance with this rationale. $^{118}$

According to the Third Restatement of the US, the functionality rule is an attempt to create a balance between the policies of exclusive rights conferred by trade symbols and free competition by imitation. Therefore, "[t]he rule excluding functional designs from the subject matter of trademarks is an attempt to identify those instances in which the anticompetitive consequences of exclusive rights outweigh the public and private interest in protecting distinctive designs." 119 The

\footnotetext{
$\overline{110}$ Restatement of Torts Sec. 742, comment a (1938); see Restatement 3rd of Unfair Competition, Sec. 17 (1995).

111 Pagliero v. Wallace, note 6.

112 Pagliero v. Wallace, pp. 343, 344.

113 W.T. Rogers Co. v. Keene.

114 Au-Tomotive Gold, Inc. v. Volkswagen of America, Inc.

115 McCarthy (1996), Sec. 7:80.

116 Au-Tomotive Gold, Inc. v. Volkswagen of America, Inc.

117 Two Pesos, Inc. v. Taco Cabana, Inc.

118 McCarthy (1996), Sec. 7:65; 7:75.

119 Restatment Third, Unfair Competition, Sec. 17, comment a (1995).
} 
"ultimate question", therefore, is whether the copier is able to "compete effectively" without copying the senior user's design. ${ }^{120}$ "Functional" in this sense means not simply that the feature serves a function, but that the feature is necessary to afford a competitor the means to compete effectively. ${ }^{121}$ "To put this differently, a functional feature is one which competitors would have to spend money not to copy but to design around [...]. It is something costly to do without [...], rather than costly to have [...]." 122

In the Qualitex decision (1995), the Supreme Court expanded the traditional rule, stating that a product feature was functional "if the exclusive use of the feature would put competitors at a significant non-reputation-related disadvantage." ${ }^{123}$ The Court pointed out that the functionality doctrine prevents trademark law from imposing unacceptable competitive burdens on competitors by impeding them "reasonably to replicate important non-reputation-related product features." ${ }^{124}$ It appears that also the Supreme Court thereby based the functionality test on the question whether there is a competitive need for imitation.

In Vornado (1995), the Tenth Circuit purported to follow the same approach taken in Qualitex:

Functionality has been defined both by our circuit, and more recently by the Supreme Court, in terms of competitive need. If competitors need to be able to use a particular configuration in order to make an equally competitive product, it is functional, but if they do not, it may be non-functional. The availability of equally satisfactory alternatives for a particular feature, and not its inherent usefulness, is often the fulcrum on which the Lanham Act functionality analysis turns. ${ }^{125}$

\subsubsection{Relevance of Alternative Shapes for Aesthetic Shapes: Traffix}

In Traffix (2001) the US Supreme Court countered such an understanding of the functionality doctrine, stating that the Qualitex decision did not purport to displace the traditional Inwood rule, and that it would be erroneous for a lower court to use it as a comprehensive legal definition for what is to be considered functional. The question whether or not the "exclusive use of the feature would put competitors at a significant non-reputational disadvantage" is a policy rationale or goal, not a courtroom definition of what is functional. ${ }^{126}$

However, the Supreme Court conceded that the availability of alternative shapes could be relevant in cases were the essential feature of a product shape lies in its aesthetic appeal: "It is proper to inquire into a significant non-reputation-related

\footnotetext{
120 Schwinn Bicycle Co. v. Ross Bicycles, Inc.

121 W.T. Rogers Co. v. Keene.

122 Schwinn Bicycle Co. v. Ross Bicycles, Inc., citing W.T. Rogers.

123 Qualitex Co. v. Jacobson Products, 1161, 1164.

124 Qualitex Co. v. Jacobson Products, p. 1165.

125 Vornardo Air Circulation Systems, Inc. v. Duracraft Corporation.

126 President Suspender Co. v. MacWilliam; McCarthy (1996), Sec. 7: 69.
} 
disadvantage in cases of aesthetic functionality, the central question involved in Qualitex. Where the design is functional under the Inwood formulation there is no need to proceed further to consider competitive necessity."127

What is notable is that although the rationale behind Traffix is a utilitarian one, the Supreme Court does not contest the existence of aesthetic functionality as such. By allowing an application of the competitive need test in a situation where the essential function of a shape lies in its aesthetic appeal, it even concedes that there may be cases in which the aesthetic appeal of a shape may serve a function in the doctrinal sense.

\subsubsection{The Role of Prior Patents}

Some legal writers have misconstrued the law by stating that when patent rights expire, the mark of the patented article will automatically fall into the public domain along with the invention of the patent. ${ }^{128}$ However, there is no rule of law that the trademark of a patented article automatically falls into the public domain when the patent expires. ${ }^{129}$

To obtain a utility patent, an inventor must only show that an invention is useful, novel and non-obvious. "Configurations can simultaneously meet these requirements and at the same time be non-functional in trade dress parlance". ${ }^{130}$ Therefore, trademark rights that continue beyond the expiration of a patent do not "extend" the patent monopoly. Such rights exist independently of the period, under different laws and for different reasons. The termination of either has no legal effect on the continuance of the other. ${ }^{131}$ It follows that these two bodies of law were designed to serve quite different purposes and may operate separately and without unavoidable conflict. ${ }^{132}$

However, this does not necessarily mean that patents have no relevance at all when functionality is in question. In the Traffix decision, the Supreme Court pointed out the relevance of utility patents when applying the Inwood rule: "an expired patent has vital significance in resolving a trade dress claim, for a utility patent is strong evidence that the features therein claimed are functional." ${ }^{133}$ Hence, a patent has indicative character when engaging in the functionality analysis, however, does not constitute functionality of a shape as such.

\subsubsection{Distinctiveness}

A subsidiary reason against the protection of functional features may be that the distinctiveness "varies in inverse proportion to its functionality". ${ }^{134}$ If a feature is

\footnotetext{
127 Traffix Devices, Inc. v. Marketing Displays, Inc.

128 McCarthy (1996), Sec. 12:52.

129 McCarthy (1996), Sec. 6:12.

130 Vornardo Air Circulation Systems, Inc. v. Duracraft Corporation.

131 Mogen David Wine Corp.

132 Hubbell Inc. v. Pass \& Seymour.

133 Traffix Devices, Inc. v. Marketing Displays, Inc.

134 McCarthy (1996), Sec. 7:64.
} 
functional, it is likely that all similar articles will have a similar functional feature, and one seller's feature is not likely to evoke any response in buyers that it is unique or is a distinctive symbol of origin. ${ }^{135}$ As Judge Posner observed: "Functional features are by definition those likely to be shared by different producers of the same product and therefore are unlikely to identify a particular producer." 136 Therefore, purely functional shapes will never acquire distinctiveness under the American doctrine.

\subsection{Similarities: Europe and the US}

When contrasting the US and European functionality doctrine, it is apparent that they both face similar questions. Both US and European courts have recognised the need to clarify what the relevant criteria are to determine whether a shape is to be considered functional. There seems to be a consistent understanding that functionality must be determined by way of an autonomous approach, taking into account the indicative force of the information contained in prior patents.

Nevertheless, both European and US courts have taken diverging approaches with regards to the question of what effect the existence of alternative shapes has on the functionality of the shape in question. While the ECJ has categorically dismissed the trademark applicants' arguments as to the effect of alternative shapes, the Supreme Court has now analysed this question in a more differentiated manner and decided that a concrete market analysis would indeed make sense in cases where a shape is aesthetically functional.

The Traffix decision could be interesting for European trademark practice in two ways. Firstly, the Supreme Court has stated that the availability of alternative shapes can be relevant to adjust certain outcomes already reached by way of an autonomous functionality analysis. Secondly, the competitive need will be confined to those cases in which the shapes have at least one significant aesthetic characteristic. This understanding implies that there are various degrees of functionality and that an adequate treatment of these degrees requires a concrete market analysis. Both of these implications are difficult to reconcile with the all-ornothing approach taken by the ECJ. In light of the US conception, it becomes apparent that there is a need for a refinement in European case law.

AG Mengozzi has recognised that the European functionality doctrine is infused by the US paradigm. ${ }^{137}$ In his view, European courts should therefore also approach the problem in a more differentiated manner. Following this line of argumentation, it could therefore be interesting to supplement his three-stage test with the notions that were developed by US courts.

\subsubsection{First Stage: Determining Functionality}

According to European trademark practice, once the essential characteristics are identified, one should examine if there is a necessary connection between these

\footnotetext{
135 McCarthy (1996), Sec. 7:64.

136 Publications Int'l, Ltd. v. Landoll, Inc., cited by McCarthy (1996), Sec. 7:64.

137 AG Mengozzi on Lego v. OHIM, para. 67.
} 
characteristics and the technical result when determining if a particular shape is functional. ${ }^{138}$ This procedure relies heavily on the actual wording of the Regulation.

The wording of the Regulation reflects the terms used in the famous Inwood decision: a product feature is functional if it is essential to the use or purpose of the article or if it affects the cost or quality of the article. Hence, a necessary connection would be given in cases where a feature plays an essential role in obtaining a certain technical result, determining the cost of the article. There is a common understanding in European and US doctrine that prior patents constitute a strong presumption that a shape is functional. ${ }^{139}$

As shown, the term "necessary" raises the question whether one should focus on the shape itself or engage in a market analysis looking at alternative shapes. When determining whether the essential features are functional, AG Mengozzi proposes a strictly autonomous approach. In this respect, the existence of alternative shapes cannot exclude functionality as such. What is decisive is that the shape is based on its technical function and does not serve the purpose to distinguish itself from other products. ${ }^{140}$ This is in line with the understanding adopted by the Supreme Court in Traffix: "it would be erroneous for a lower court to use it as a comprehensive legal definition for what is to be considered functional." This is also in line with the understanding of the ECJ.

\subsubsection{Second Stage}

According to AG Mengozzi, the courts will have to determine at this stage whether a hybrid shape is necessary to perform a technical function. While it is difficult to derive how to proceed at this stage from the wording of Art. 7(1)(e)(ii) CTMR, it could be worthwhile to contrast the Advocate General's approach with the approach taken by US courts.

2.3.2.1 Hybrid Shapes US judicial practice acknowledges the concept of aesthetic functionality, thereby dismissing the notion that only purely utilitarian shapes be excluded from trademark registration. Similarly, a number of European countries and the CTMR exclude protection for design features, which although not technically essential, substantially affect the value of a product. ${ }^{141}$ The fact that European law conceptually recognises the existence of aesthetic functionality raises the question of how the concepts of aesthetic and utilitarian functionality interact with each other.

The US doctrine allows for a gradual analysis of a shape's usefulness with regard to its utility on the one hand, and its appeal on the other hand. The practical advantage of this gradual conception is that it is very likely that these different types of "functionality" will overlap to a certain extent. It appears from the wording in Inwood that even the US Supreme Court, the creator of the traditional utilitarian

\footnotetext{
138 AG Mengozzi on Lego v. OHIM, para. 65.

139 See supra, 2.1.3.1.1; 2.2.5.

${ }^{140}$ Körner and Gründig-Schnelle (1999), p. 535, 537.

141 Article 7(1)(e)(iii) CTMR.
} 
rule, accepted the possibility that both aesthetic (cost) and utilitarian (quality) features may at the same time contribute to a product's usefulness. The practical advantage of this gradual conception is that it is indeed very likely that these different types of "functionality" will overlap to a certain extent.

For a sign to qualify as "aesthetically functional" within the meaning of Art. 7(1)(e)(iii) CTMR, it is necessary to determine whether or not that sign consists "exclusively" of a shape that gives substantial value to the good. Article 7(1)(e)(iii) CTMR is given an extremely narrow interpretation, excluding cases in which the value of the shape for which registration is applied can be attributed to other factors. ${ }^{142}$ This narrow conception seems to be justified when taking into account that, given a broader understanding, virtually any trademark consisting of a shape would be barred from registration since all products of industrial utility are subject to design considerations before being launched to the market. ${ }^{143}$

On the other hand, the term "exclusively" has been given a broader meaning in Philips, where it was only held that it must be read in the light of the expression "essential characteristics which perform a technical function". ${ }^{144}$ While the ECJ still contends that Art. 7(1)(e)(ii) CTMR should only apply to shapes that are purely functional in a utilitarian sense, such a narrow conception does not seem to be justified here. The inclusion of hybrid shapes in the functionality analysis would not lead to the total elimination of all shape trademarks, but rather allow for a more nuanced examination, ruling out certain shapes from registration at a later stage, where necessary. Therefore, I suggest that the term "exclusively" should in fact be read as "some essential characteristics which perform a technical function" in order to include various degrees of functionality. Only if such hybrid shapes are included, will courts be able to engage in a tailor-made, case-by-case analysis giving effect to the underlying interest to the appropriate extent for every individual case. Therefore, I agree with the Advocate General that hybrid shapes should be included and dealt with at the second stage of the examination.

2.3.2.2 Alternative Shapes-Competitive Need Test As previously shown, the relevance of alternative shapes is highly controversial, not only in the European functionality analysis. The idea that the existence of functionally equivalent alternatives on the market does to some extent affect the functionality analysis is also a known concept under US trademark law where it is understood as the competitive need test. As was established in the Traffix decision, the availability of alternative shapes is not suitable to serve as a legal definition of what is to be considered functional. If it has been established that a product shape is functional in relation to its utility, using the guidelines as previously discussed, the availability test cannot be applied to render a functional shape non-functional.

However, the Supreme Court conceded in Traffix that the availability of alternative shapes could be relevant in cases were the essential feature of a product shape lies in its aesthetic appeal: "It is proper to inquire into a significant non-

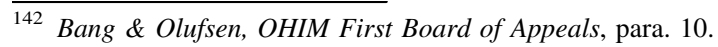

143 Bang \& Olufsen, OHIM First Board of Appeals, para. 26.

144 Philips v. Remington, Case 299/99 (2002), paras. 79, 80, 83.
} 
reputation-related disadvantage in cases of aesthetic functionality, the central question involved in Qualitex."145

Embedding this approach into European terminology would imply that the availability test is to be applied only to the case of hybrid shapes, meaning when a shape is partially comprised of non-functional, or rather aesthetic parts. This has two implications for the interpretation of Art. 7(1)(e)(ii) CTMR: first, contrary to the approach purported by the ECJ, the functionality provision should also be applied to hybrid shapes; second, the inclusion of hybrid shapes within the scope of the provision requires an examination of alternative shapes. In this respect, a concrete market analysis would operate as a filter in order to achieve results that comply with the underlying public interest. The procedure suggested in Traffix thus matches the second stage as proposed by AG Mengozzi.

The Supreme Court in Traffix, however, does not provide guidance as to why the competitive need becomes relevant only in the case of aesthetic shapes. It appears that AG Mengozzi has traced back the reason to the purpose of the provision, which is to "overwhelmingly protect competition". ${ }^{146}$ "The examination of a sign composed in part of functional elements would have to be subject to a requirement that any industrial property rights granted must not lead to a significant nonreputation-related disadvantage for competitors vis-à-vis their own sign." ${ }^{147}$ In cases of hybrid shapes it makes sense to inquire into a concrete market analysis since the complexity of the shape requires a more detailed analysis than can be derived from a merely autonomous examination. "For, in a situation such as that described, it is not inconceivable that several or many of those functional characteristics are essential for market competitors." 148 Therefore, the existence of alternative shapes should be included in the functionality analysis, taking into account interoperability and the requirement of availability, which represent the public interest also underlying Art. 7(1)(e)(ii) CTMR. ${ }^{149}$

Contrary to the trademark applicants' submissions, however, the existence of alternative shapes cannot operate as a constitutive element in the functionality analysis. Instead, it may adjust certain outcomes appropriately by facilitating a concrete market analysis. While such an analysis would be futile where a shape has already been held purely functional, it may prove to be extremely helpful when dealing with a hybrid shape since such a shape cannot be held functional or nonfunctional by way of an abstract analysis.

\subsubsection{Third Stage: Distinctiveness}

Both in European and American case law, the distinctiveness is considered to be a subsidiary obstacle to the registration of a functional shape. Distinctiveness is to be measured by the perception of the average, well-informed and circumspect

\footnotetext{
$\overline{145}$ Traffix Devices, Inc. v. Marketing Displays, Inc.

146 AG Mengozzi on Lego v. OHIM, para. 74.

147 AG Mengozzi on Lego v. OHIM, para. 74.

148 AG Mengozzi on Lego v. OHIM, para. 72.

${ }^{149}$ AG Mengozzi on Lego v. OHIM, para. 74.
} 
consumer. ${ }^{150}$ When a shape is purely functional, its essential features will probably occur as part of many other products and the target consumer will be not be likely to associate them with a particular producer.

Under the US approach, a purely functional feature will never be distinctive. Only a certain degree of non-functional, aesthetic appearance will allow the consumer to recognise an indication of origin. Likewise, it was argued by the German Federal Supreme Court that a three-dimensional shape can only be distinctive if it deviates from the normative industrial standard and thereby indicates origin. $^{151}$

In contrast, the ECJ has held that when determining the distinctiveness of a functional shape, the same standards should apply as they would for other kinds of signs. ${ }^{152}$ Although it recognises the practical difficulty when having to prove distinctiveness for a functional shape, it rejects the argument that distinctiveness could only be acquired by the addition of mere embellishments as argued by Philips. ${ }^{153}$ The reason for this different conception is that under European trademark law, distinctiveness is assessed from the perspective of the consumer, whereas functionality is to be assessed by way of a technical analysis carried out by the registration body. Since the standards of assessment are different, a purely functional shape can still be perceived as being distinctive by the consumer. Conversely, a hybrid shape could be perceived as being purely technical and nondistinctive. Even though these cases might in fact be very rare, these different standards of assessment provide for a more flexible method to assess whether a shape is distinctive than provided for under the US approach. In this respect, the deviation from the US model is to be approved.

\section{Conclusion}

Imitation and identification are two important objectives in intellectual property rights that require a continuous balancing act in order to provide for an optimum of market efficiency. The buyer's need to imitate is a legitimate endeavour, unless the victim of copying has a legal right that has been infringed. ${ }^{154}$ Such exclusive rights will typically be granted on a temporary basis by means of patent or design protection. By granting a period of exclusivity for technical solutions and innovative designs, patent and design law seek to create a compromise in order to reward the producer for his innovation on the one hand and to respect the buyer's right to imitate on the other hand.

Conversely, trademark law grants the producer a permanent right of protection against competitors who create a likelihood of confusion by making their goods

\footnotetext{
150 Gut Springenheide and Tursky.

151 As has been argued by the German Federal Supreme Court, 24 May 2007, Case No. I ZB 37/04, 2008 GRUR 71 - Fronthaube.

152 Philips v. Remington, Case 299/99 (2002), paras. 49, 50.

153 Philips v. Remington, Case 299/99 (2002), paras. 49, 50.

154 Brown (1987), p. 1357.
} 
appear to be those of the first seller. By allowing the producer to register a sign, trademark law assures that the producer alone, and not an imitating competitor, will reap the financial and reputation-related rewards associated with a desirable product. $^{155}$ This comprehensive protection seems justifiable when taking into account that a clear indication of origin is also beneficial for public purposes. The prevention of consumer confusion is an important requisite for efficiency in a market, in the sense that a clear identification of origin will reduce the consumer's costs of making purchase decisions. Furthering this purpose is the beating heart of trademark law. ${ }^{156}$ In that sense, it has been affirmed by established case law that trademark law constitutes an essential element in the system of competition in the European Union. ${ }^{157}$

Since the scope of trademark rights has been extended in past decades to the effect that it also includes the protection of product shapes, trademark law appears to be overtaking both patent and design law, rendering their compromise solution obsolete. The conflict becomes manifest where a purely functional shape is alleged to serve as a trademark: an unlimited trademark protection of a purely functional shape could lead to permanent protection of the product itself. ${ }^{158}$ Hence, granting permanent protection for functional shapes would circumvent the purpose of patent and design law and would thus be irreconcilable with the system of intellectual property rights that has been developed in the European Union.

As a matter of fact, the growing market and the increasing supply of products require trademark mechanisms to adapt to the fierce competition between producers by expanding their scope. Regardless, consumer confusion should not be prevented at any price. Therefore, it is appropriate to limit the scope of trademark protection in a reasonable manner where it is necessary. Properly understood, the functionality rule is the safeguard that mediates the conflicts between the policies of freedom to copy the elements of an expired utility patent and the exclusive rights conferred by federal trademark law. ${ }^{159}$

In Europe, this idea has been reflected in Art. 7(1)(e)(ii) CTMR, which makes an attempt to balance the competing interests associated with the registration of functional shapes. Unfortunately, the wording of the provision creates many questions. Moreover, the guidelines that have been developed so far in European trademark practice, especially the rulings in the two precedent cases Philips and Lego, have introduced some additional elements of vagueness.

When construing the wording of Art. 7(1)(e)(ii) CTMR, one should take into account the general principle to interpret exceptions narrowly. However, that does not necessarily mean that hybrid shapes should be excluded per se from the scope of Art. 7(1)(e)(ii) CTMR. In order to give effect to the underlying interest, namely the prevention of monopolies, all degrees of functionality should call for a thorough

\footnotetext{
155 Qualitex Co v. Jacobson Products Co., Inc.

156 Brown (1987), p. 1357.

157 Lego v. Mega Brands, Case C-48/09 P (2010), para. 38.

158 Körner and Gründig-Schnelle (1999) p. 535-537.

159 Thomas \& Betts Corp. v. Panduit Corp., 1026, 1031.
} 
examination by the registration body. Thereby, the existence of alternative shapes could provide for a detailed market analysis in order to find an appropriate solution.

By advocating a gradual analysis of functionality, taking into account other market alternatives, the view proposed in this work supplements the findings of AG Mengozzi, which also find recognition in the US case law. It will be upon the European courts, especially the ECJ, to provide for interpretative guidance in order to bring about just and consistent outcomes in the future.

Acknowledgment I would like to express my gratitude to my supervisor Dr. Dev S. Gangjee, Lecturer at the London School of Economics, who was an exceptionally inspiring and encouraging mentor while offering invaluable support and guidance for my work.

\section{Appendix: Materials}

Legislation

Council Directive (89/104/EEC) of 21 December 1988 of the Community Trade Mark

Council Regulation No. 40/94 of 20 December 1993 of the Community Trade Mark

Council Regulation (EC) No. 207/2009 of 26 February 2009 of the Community Trade mark

Council Regulation (EC) No. 6/2002 of 12 December 2001 on Community Designs

Lanham Trademark Protection Act of 1946 (United States)

Third Restatment of Unfair Competition of 1995 United States

Cases

\section{ECJ}

Dyson Ltd v. Registrar of Trade Marks, Case C-321/03, decision of 14 September 2006; opinion of AG Léger

Gut Springenheide and Tusky, Case C-210/96, decision of 16 July 1998

Koninklijke Philips Electronics NV v. Remington Consumer Products, Case C-299/99, decision of 18 June 2002; opinion of AG Ruiz-Jarabo Colomer

Lego v. OHIM/Megabrands, Case C-48/09 P, decision of 14 September 2010; opinion of AG Mengozzi

Linde AG, Winward Industries, Rado Watch Co Ltd., Joint Cases C-53/01 C-54/

01 C-55/01, decision of 8 April 2003

Windsurfing Chiemsee, Joined Cases C-108/97 C-109/97, decision of 1999

\section{General Court}

Lego v. OHIM/Mega Brands, CFI, Case T-270/06 of 12 November 2008 


\section{OHIM}

Bang \& Olufsen v. OHIM, Case R 497/2005-1, decision of 10 September 2008

\section{Germany}

German Federal Supreme Court, 24 May 2007, Case No. I ZB 37/04, 2008 GRUR 71 - Fronthaube

German Federal Supreme Court, July 16 2009, Case No. I ZB 53/07, 2010 GRUR 231 - Legostein

German Federal Supreme Court, December 15 2006, Case No. I ZB 33/04, 2006 GRUR 679 - Porsche Boxter

\section{United Kingdom}

Koninklijke Philips v. Remington, Court of Appeals, FSR (30) 537 (CA) (2006)

\section{United States}

Au-Tomotive Gold, Inc. v. Volkswagen of America, Inc., Ninth Circuit, 457 F.3d 1062, 80 U.S.P.Q.2d 1293

Cooper Industries, Inc. v. Leatherman Tool Group, Inc., Supreme Court (2001), 532 U.S. 424, 121 S.Ct. 1678, 149 L.Ed.2d 674, 58 U.S.P.Q.2d 1641, 1648

Hubbell Inc. v. Pass \& Seymour, (1995), 883 F. Supp. 955, 35 U.S.P.Q.2d 1760 (S.D.N.Y. 1995)

Inwood Laboratories, Inc. v. Ives Laboratories, Inc., Supreme Court 456 U.S. 844, 850, n. 10, 102 S.Ct. 2182, 72 L.Ed.2d 606

Jay Franco \& Sons, Inc. v. Franek, (2010), 615 F.3d 855, 96 U.S.P.Q.2d 1404, C.A.7 (Ill.) (No. 09-2155)

Kellogg's Co. v. National Biscuit Co, Supreme Court (1938), 305 U.S. 111

Kline \& French Laboratories v. Clark \& Clark, Third Circuit (1946), 157 F.2d 725, 730-731

Marvel Co. v. Pearl, Second Circuit (1904), 133 F. 160, 161-62

Mogen David Wine Corp., United States Court of Customs and Patent Appeals (1964), 328 F.2d 925, 930, 140 U.S.P.Q. 575 (C.C.P.A. 1964)

Moseley v. V Secret Catalogue, Inc., Supreme Court (2003), 537 U.S. 418, 123 S.Ct. 1115, 155 L.Ed.2d 1

Pagliero et al. $v$ Wallace China Co., Ltd., Ninth Circuit (1952), 198 F.2d 339, 95 U.S.P.Q. 45

President Suspender Co. v. MacWilliam, Second Circuit (1916), 238 F. 159

Publications Int'l, Ltd. v. Landoll, Inc., Seventh Circuit (1998), 164 F.3d 337, 49 U.S.P.Q.2d 1139

Qualitex Co v. Jacobson Products Co., Inc., Supreme Court (1995), 514 U.S. 159, 115 S.Ct. 1300, 131 L.Ed.2d 248, 63 USLW 4227, 34 U.S.P.Q.2d 1161

Schwinn Bicycle Co. v. Ross Bicycles, Inc., Seventh Circuit (1989), 870 F.2d 1176, 1189 
Thomas \& Betts Corp. v. Panduit Corp., U.S. Court of Appeals Seventh Circuit (1998), 46 U.S.P.Q.2d 1026, 1031

Two Pesos, Inc. v Taco Cabana, Inc., Supreme Court (1992), 505 U.S.763, 774, 120 L.Ed.2d 615, 112 S.Ct. 2753

Traffix Devices v. Marketing Displays, Supreme Court (2001), 532 U.S. at 34, 121 S.Ct. 1255

Vuitton et Fils S.A. v. J. Young Enter, Ninth Circuit (1981), 644 F.2d 769

W.T. Rogers Co. v. Keene, Seventh Circuit (1985), 778 F.2d 334

Websites

http://works.bepress.com/graeme_dinwoodie/36

Studies

"Study on the Overall Functioning of the European Trade Mark" System presented by the Max Planck Institute for Intellectual Property and Competition Law, 15 February 2011

\section{References}

Bently L, Sherman B (2009) Intellectual property law., Oxford University Press Inc., New York.

Brown RS (1987) Design protection: An overview. UCLA Law Review 1357.

Columbia Law Review Association (1964) Unfair competition and the doctrine of functionality. Columbia Law Review 544.

Ingerl R, Rohnke C (2010) Markengesetz, Gesetz über Marken und sonstigen Schutz von Kennzeichen., 3rd edn. Beck, Munich.

Körner E, Gründig-Schnelle K (1999) Markenrecht und Produktschutz durch die dreidimensionale Marke.GRUR 101:535-541.

Litman J (1982) The problem of functional features: trade dress infringement under section 43(a) of the Lanham Act. Columbia Law Review 77.

McCarthy JT (1996) McCarthy on trademarks and unfair competition. 4th edn, Deerfield, Ill., Clark Boardman Callaghan. 